\title{
XYLOGENESIS AND PHLOEMOGENESIS OF NORWAY SPRUCE IN DIFFERENT AGES STANDS AT MIDDLE ALTITUDINAL ZONE
}

\author{
Jana Hacurová ${ }^{1,2}$, Jakub Hacura ${ }^{1}$, Vladimír Gryc ${ }^{1}$, \\ Jakub Čern Ý ${ }^{2}$, Hanuš VavrčíK ${ }^{1}$ \\ ${ }^{1}$ Mendel University In Brno \\ Czech Republic \\ 2Forestry and Game Management Research Institute \\ Czech Republic
}

(Received April 2020)

\begin{abstract}
This study aimed to determine the influence of the stand age and selected weather conditions on the cambial activity, xylem and phloem formation and their development. For the analysis, microcores were taken weekly from two corresponding stands of Norway spruce (Picea abies (L.) Karst.) with various ages (35- and 106-years-old) during the growing season 2012 in the Czech Republic. Young specimens were characterised by higher cambium activity; however, more considerable variation and imbalance were found there. In old trees, delayed processes during the development of the xylem and phloem at the cell level were proved. The cambium activity started in March till mid-April, and it lasted for 22 weeks in both cases. The commencement of xylogenesis was established in the first half of May. In both investigated stands, the fully lignified ring was observed at the end of October. For the creation of most xylem cells, it was required 124 and 121 days in the young and old stands, respectively. Daily increment of 0.57 (young) and 0.49 (old) cells on average was observed during the active xylem growth. The relationship between air temperature and wood cell formation for both age groups was recorded. The precipitation influenced wood development just in the case of the young trees. Phloem formation was resistant to external influence according to the Pearson correlation coefficient.
\end{abstract}

KEYWORDS: Xylogenesis, phloemogenesis, Norway spruce, cambium, age, environmental factors. 


\section{INTRODUCTION}

In the last two centuries, Norway spruce (Picea abies (L.) Karst.) was the most favoured tree species in central Europe. Recently complex of problems with stands of Norway spruce is widely recognised (Diaci 2002). Formation and course of wood formation is a plastic process responding to the external and internal conditions of the tree (Schweingruber 2007). The understanding of these processes during the growth of the tree at the cellular level is also essential for the adaptation of tree species to a rapidly changing climate, especially to global drought-induced stress (Kijowska-Oberc et al. 2020). Radial growth of trees is a result of the activity of two lateral meristems; i.e. a vascular cambium and a cork cambium (phellogen). The vascular cambium produces secondary phloem and secondary xylem cells centrifugally and centripetally, respectively (Panshin and de Zeeuv 1980, Larson 1994, Gričar 2007).

The processes in the cambial zone are following by the complex of developmental processes of differentiation. The differentiation can be divided into several consecutive phases: postcambial cell growth, secondary cell wall thickening and, in tracheids, also lignification of the cell wall and programmed cell death (Gričar 2007, Rossi et al. 2012, Gričar et al. 2014).

The duration of the cambial activity and cell developing are reliant on the tree species, site, climate conditions of the growing season and other factors. Among constraining environmental factors mainly belong to the length of photoperiod, air temperature, the sum of precipitation, soil moisture, incident radiation, altitude, etc. On the contrary, the stand age, the genetic disposition, the plant vitality pertains to main internal factors (Panshin and De Zeeuw 1980, Gričar 2007, Speer 2010, Gryc et al. 2012).

The wood of conifers is composed of tracheids and parenchyma. The process of wood formation (xylogenesis) is a non-predestined phenomenon. This phenomenon is a final plastic product of the interaction between the genotype and the environment (Savidge 1996, 2000). The cambial activity under normal site conditions is more frequent on the xylem than the phloem side (Gričar and Čufar 2008). The phloem cells' formation is more stable and less susceptible to decline triggered by external site conditions (Panshin and De Zeeuw 1980, Gričar 2007, Gričar and Čufar 2008, Gričar 2012).

The phloem of coniferous trees consists of sieve cells and the phloem parenchyma (Larcher 2003). Parenchyma cells are long-lived, store and transport of assimilates, produce various excretes. Sieves elements provide transport of assimilates and are short-lived (Schweingruber et al. 2007, Schweingruber et al. 2019). Secondary phloem includes all bark tissues derived from vascular cambium during the secondary growth (Gričar and Čufar 2008). The phloem contains both a part of the early and late phloem. The late phloem is half-sized in the radial direction compared to the larger elements of early phloem (Antonova and Stasova 2006). The phloem increment is exposed to relatively rapid secondary changes of tissues (cell collapse, sclerification, the formation of axial parenchyma). Therefore, only the structure of one or two youngest annual phloem increments is recognisable. Older non-conductive tissues eventually disintegrate in the radial direction deform, and later often completely collapse (Gričar 2008).

The study is aimed to analyse the processes of xylogenesis and phloemogenesis of Norway spruce (Picea abies (L.) Karst.). Stands are located at middle altitudinal zone. The effect of the stand age and selected climatic variables on progress of Norway spruce was examined.

It was expected that: (1) The stand of the old trees will report the weaker cambial activity compared to the young stand; (2) The age will also influence the dynamics of tracheid differentiation, their resulting number and phloem growth processes; (3) The site factors (seasonal air temperature, precipitation) will affect the progress of xylogenesis and phloemogenesis processes. 


\section{MATERIALS AND METHODS}

\section{Study site}

All measurements and samplings performed in the presented study were conducted in pure old and young Norway spruce (Picea abies (L.) Karst.) stand in Rájec-Němčice, long-term experimental station $\left(49^{\circ} 29^{\prime} \mathrm{N}, 16^{\circ} 43^{\prime} \mathrm{E}, 610 \mathrm{~m}\right.$ a.s.1.). These studied stands were established in 1901 and 1978.

The experimental plot belongs to Czech Carbon Observation System (CzeCOS). It occurs under moderate continental climatic conditions with $7.0^{\circ} \mathrm{C}(1961-2000)$ and $643.4 \mathrm{~mm}$ (1957-2000) of annual mean temperature and annual mean precipitation, respectively (Hadaš 2002). Climate diagram (Fig. 1) shows the monthly volume of precipitation, air temperature during the growing season 2012 and possible period with rainfall deficit and drought risk. The modal oligotrophic cambisol was developed on the acid granodiorite bedrock (Menšík et al. 2009). The forest type in the study site is characterised as abieto-fagetum oligo-mesotrophicum (Viewegh et al. 2003).

In total, 12 sample trees were randomly selected for the analysis. Six selected trees were sampled both in the young (35-year-old) and old (106-year-old) spruce stand with the diameter at breast height of $19.2 \mathrm{~cm}$ and $38.0 \mathrm{~cm}$ on average, respectively. Stand's structural and dendrometric characteristics are described in Světlík et al. (2016) and Černý et al. (2018) for the old and young spruce stand, respectively.

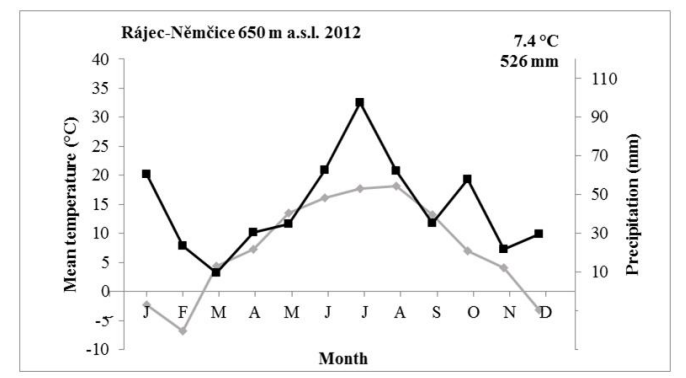

Fig. 1: Climate diagram according to Walter and Lieth (1960) at Rájec-Némciice research plot $(650 \mathrm{~m}$ a.s.l.), black line - precipitation $(\mathrm{mm})$, grey line - mean temperature $\left({ }^{\circ} \mathrm{C}\right)$, the situation when black line is lower than the grey line is deemed as a period with rainfall deficit with possible drought risk.

\section{Sample collection and data processing}

All samples (microcores) were collected at weekly intervals during the growing season (March-November 2012). The sampling was implemented using a tool called Trephor (Rossi et al. 2006a). The microcores (1.8 $\mathrm{mm}$ in diameter) were taken at the breast height $1.3 \mathrm{~m}$ above the ground at locations spiralling around the stem perimeter. Each sample contained phloem, cambial zone and xylem. The samples were always taken at least $5 \mathrm{~cm}$ far away from each other to avoid getting traumatic resin ducts. After sampling, the microcores were fixed in FAA solution, where the samples were left for one week. Subsequently, they were put in $30 \%$ ethanol. The microcores were then dehydrated in the ethanol series (70\%, 70\%, 90\%, 95\% and 100\%), impregnated by paraffin and embedded in paraffin blocks (Rossi et al. 2006a). The Leica RM2235 rotary microtome (Leica Microsystems GmbH, Germany) was used to obtain sections with a thickness of $12 \mu \mathrm{m}$. The sections were glued to slides using Albumin and then dyed in Safranin and Astra blue for staining lignified and not lignified cell walls, respectively. The resulting permanent 
preparations were analysed using the Leica DMLS microscope (Leica Microsystems GmbH, Germany) and scanned by the Leica DFC 295 digital camera (Leica Microsystems GmbH, Germany). The beginning of the cambial activity was established as the date of sampling, when it was possible to observe the first phloem cells, in two (from three) randomly chosen rows. The same measurement was carried out in the phloem and xylem parts. The progress of the various stages of the tracheid differentiation was analysed in the xylem part, depending on the colouring of cells (Rossi et al. 2006a).

For identification of the first and the second stage of the cell growth, a polarizing filter was used. The filter highlighted cells with already formed secondary walls. Applications Image ${ }^{\circledR}$ (Wayne Rasband, MD, USA) was used to determine the length of the cambial zone, xylem, and phloem parts.

Mean daily temperatures with air humidity and daily precipitation were measured using EMS32A sensor (EMS, Czech Republic), rainfall gauges (Pronamic Pro, Denmark), and CS650 sensors (Campbell Scientific, Inc., UT, USA), respectively, for the evaluation of site condition's influence on the production of wood and phloem cells.

Statistical analyses (ANOVA, t-test) were performed using STATISTICA ${ }^{\circledR}$ software, version 10.0 (StatSoft Inc., OK, USA) using the confidence level of $0.95(\alpha=0.05)$ throughout the whole study. The eq. 1 was used for the Gompertz function (Gričar et al. 2008):

$$
\mathrm{y}=\mathrm{A} \exp (-\exp (\mathrm{B}-\mathrm{k} \mathrm{t}))
$$

$y$ - weekly cumulative increment expressed in the sum of cells,

$t$ - time showing the day of the year,

$A$ - upper asymptote representing the maximum number of cells,

$B$ - x-axis placement estimating the beginning of the cambial activity,

$k$ - inflexion point on the curve (rate of change parameter).

For curve fitting, Fityk program version 1.3.1 (Wojdyr 2010) was used.

\section{RESULTS}

\section{Cambial activity}

At the beginning of the growing season (DOY 96, April 5), the cambial zone consisted of six cells on average both in the young and old stand. The peak of cambial activity was reached in mid-May (DOY 138) for both studied stands. The maximum number of cambial cells (CC) was, on average, 12 and 13 in the young and old sample trees, respectively. In the young stand, the high variability of the maximum cells' number among sample trees was observed according to the standard deviation (3.7 and 1.0 for the young and old trees, respectively).

The highest value of the average number of the cambial cells in the individual tree was 18 and 14 for the young and old sample trees, respectively. Based on the two-sample t-test, no significant differences in average number of cambial cells in young and old sample trees were found $(p=0.11$, Fig. 2).

In all sample trees, the first phloem cells were formed in March till mid-April. The cambial activity commenced on average on DOY 101 (April 10) and DOY 112 (April 21) in the young and old sample trees, respectively. The time range when the cambial activity started within each tree was 5 in the young and 3 weeks in old stand. If the date of observation of the first phloem cell over the studied sample trees and the period of one week before this date were counted, mean 
air temperatures per week of 5.3 and $8.6^{\circ} \mathrm{C}$ were found in the young and old stands, respectively.

The cambial activity finished with no observed wood cell at the stage of radial expansion. This moment differed among individual sample trees where the young and old stand finished the cambial activity on DOY 257 (September 13) and DOY 264 (September 20) on average, respectively. For more details, all sample trees finished the production of their new cells no later than DOY 271 (September 27) in contrast some of the young sample trees completed the cambial activity before DOY 236 (August 23). Thus, the higher variability was observed in the young stand. If the dependency of the cambial activity (number of CC) on week average temperature were assessed, the Pearson correlation coefficient showed relationship $(r=0.43$ and $r=0.48$ in the young and old stand, respectively).
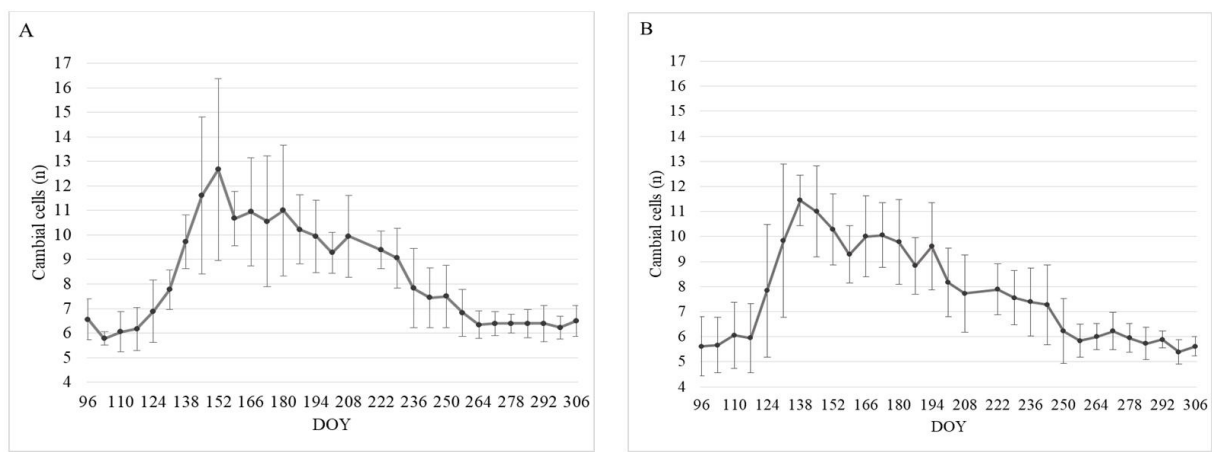

Fig. 2: Cambial activity in the young (A) and old (B) Norway spruce stand within the observed growing season 2012. CC-cambial cells; DOY - the day of the year. Whiskers depict standard deviations.

For both investigated Norway spruce stands with different age, the same length of the cambial activity duration (i.e. the beginning of the phloemogenesis till the end of the cell formation at the PC stage) was startlingly noted. However, the period of the cambial activity was shifted because both earlier commencement and the end of the cambial activity were observed in the young stand. For all studied sample trees, the average length of the cambial activity was 154 days (22 weeks).

\section{Phloemogenesis}

The maximum number of early phloem cells (EP) was averaged around 4 and 3-4 in the young and old stand, respectively. In general, the first axial parenchyma (AP) appeared between mid-May to end-May; however, in some of the old sample trees later (mid-June). During the whole growing season, only one AP cell was commonly formed in each tree. Late phloem (LP) was created by 5 and $4-5$ cells in the young and old stand, respectively. At the end of the growing season 2012, the EP/LP ratio was 4:5 for both stands (the mentioned ratio was calculated as the mean value of measurements for the last three weeks). Generally, the young stand was characterised by the higher formation of the phloem cells ( 10 cells on average of all young trees) than in the old stand (9 cells on average of all old trees; Fig 3). In both studied stands, the average number of cells was assessed from the last three following weeks, sampling at the end of the growing season 2012 .

Based on ANOVA, the difference in means of the maximum number of cells in the young and old sample trees was found $(p=0.42)$. 


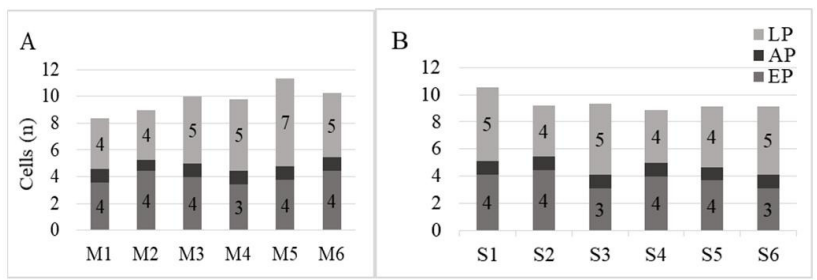

Fig. 3: Phloem formation in the wood of young $(A)$ and old (B) Norway spruce stands within the investigated growing season 2012. LP - late phloem; AP - axial parenchyma, EP - early phloem; S1-S6 - the label of sample tree in the old stand; M1-M6 - the label of sample tree in the young stand.

\section{Xylogenesis}

The first wood cells (PC) emerged from the cambial zone in the first half of May in both stands differed by its age (Young-DOY 124; Old - DOY 131). The cell formation was more rapid and efficient in the young trees, where three cells per week, on average, were formed compared to just one cell created in the old stand (Fig. 5). The primary cells at the stage of secondary cell wall formation (SW) appeared in mid-May (DOY 136) regardless of the age of the sample tree.

In the young stand, cells entered the stage of mature cells (MT) on May 31 (DOY 152); whereas the first MT cells were observed on June 14 (DOY 166, Fig. 5) in the old stand. Utterly the lignified cells were first recorded on October 25 (DOY 299) at the same time for both investigated stands (differed in the age). After the full lignification of all cells, the process of differentiation into mature wood elements had been completed. The total number of newly created cells was 68 and 57 for the young and old stand, respectively (Fig. 6).

The maximum weekly increment of the cells was 5.88 and 4.99 cell per week (1.51 and 1.40 cell per day) in the young and old stand, respectively (Fig. 4). This weekly maximum was noted in the second half of June (DOY 166; 173). The average weekly increment was 2.28 and 1.89 cell per week ( 0.58 and 0.46 cell per day) in the young and old stand, respectively. For calculation of the mean weekly and daily increment, just measurement from the period of the cambium activity was assessed. Data are based on the Gompertz function.

For the formation of most xylem cells, 124 and 121 days in the young and old stand, respectively, were required (Fig. 6).

Based on ANOVA, no significant difference in the maximum number of cells between the young and old stand was proven $(p=0.18)$.
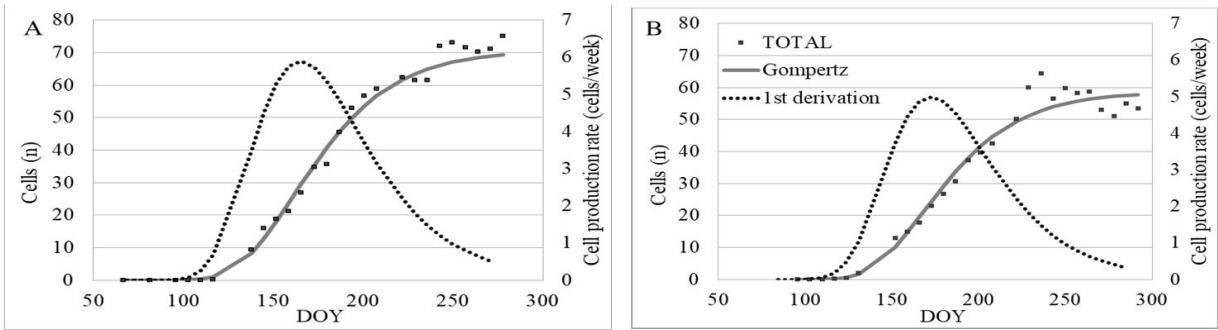

Fig. 4: Number of cells and its Gompertz function in the young (A) and old (B) Norway spruce stand within the studied growing season 2012. 

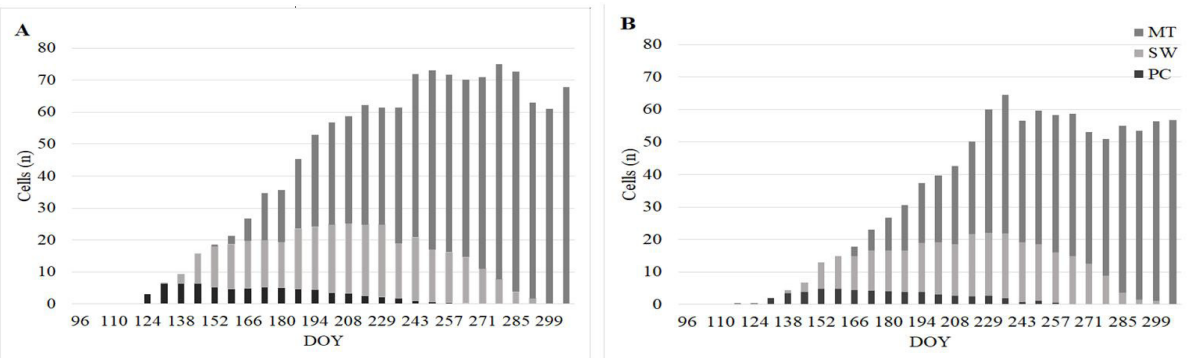

Fig. 5: Differentiation of xylem in the young (A) and old (B) Norway spruce stand within observed growing season 2012. PC-post-cambial growth; SW-secondary-wall thickening; $M T$ - mature cells; DOY - the day of the year.
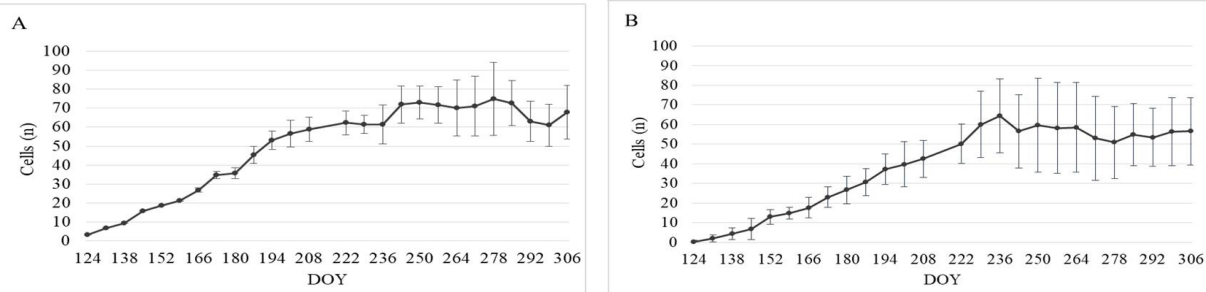

Fig. 6: Growth of xylem in the young (A) and old (B) Norway spruce stand within the investigated growing season 2012. DOY - the day of the year. Whiskers show standard deviations.

\section{The effect of site conditions on the production of wood and phloem cells}

The number of the wood cells formed per week followed the values of average weekly air temperature with a time lag of 7-14 days. During, the correlation test between the average weekly air temperature (one week before sampling retrospective) and the number of xylem cells formed in the previous week, Pearson correlation coefficients of 0.33 and 0.45 for the young and old stand, respectively, were calculated. It was observed variance in reaction in both young and old stand and their relationship with precipitations. Besides, this finding confirmed the Pearson correlation coefficient (0.37 and 0.08 for the young and old stand, respectively).

Based on Pearson correlation coefficient, it was not validated relationship between the creation of new phloem cells and the weekly average of air temperature before sampling $(r=0.25$ and $r=0.07$ in the young and old stands, respectively). The reaction of the phloem growth to week average precipitation before sampling was not significant, for the young trees even negative $(p=-0.32$ and $p=0.06$ in the young and old stand, respectively).

\section{DISCUSSION}

At the beginning of the growing season (DOY 96) the cambial zone consisted of six cells on average in both stands independently of the tree's age. Similar values (6-7 CC) were measured by Gričar (2007) in old mixed stand composed of Silver fir (Abies alba Mill.) and Norway spruce (Picea abies (L.) Karst.). The same results (6-7 CC) were published by Rossi et al. (2009) in seven-year-old plants (Abies balsamea L.). Rossi et al. (2008a) reported 5-8 cambial cells on 
average for Larix decidua, Pinus cembra and Picea abies independent of their age (50-80 years old) and (200-350 years old). Moreover, Hacura et al. (2014) confirm 7-10 CC at the beginning and 5-8 CC at the end of the growing season in Norway spruce. On the contrary, Gryc et al. (2011) reported 3-6 cambial cells during dormancy at the same site (Rájec-Němčice) and the same stand (old, in 2009). Bannan (1962) even reported only 1-5 cells in the cambium during dormancy in Pinus strobus L. stand. If some other authors (Kutscha et al. 1975, Larson 1994, Cocozza et al. 2016) measured the lower number of cambial cells, this fact could be caused by many factors, such as tree species, diverse age of trees, different site conditions, tree part of sampling acquisition, tree vitality, etc., as well as by different methodological approach.

Generally, the activity of the cambial zone begins with a mean daily air temperature higher than $4.4^{\circ} \mathrm{C}$ lasting at least one week (Wilcox 1962). Gričar (2007) presented the minimum temperature limit for the commencement of cambial activity to be $5.0^{\circ} \mathrm{C}$. Deslauriers et al. (2008) noted this limit of minimum air temperature $5.5^{\circ} \mathrm{C}$. In contrast, Rossi et al. (2007) found that the xylogenesis was activated with daily air temperatures ranged between 5.6 and $8.5^{\circ} \mathrm{C}$. In this study, the period, when first phloem cells were observed, was characterised by daily average (per week before) temperatures of 5.3 and $8.6^{\circ} \mathrm{C}$ for the young and old sample trees, respectively.

Within the 2012 growing period, the first cells of PC were observed on DOY 124 (May 3) and DOY 131 (May 10) in the young and old sample trees, respectively. This period is considered the beginning of the cambial activity by many authors (e.g. Gričar and Čufar 2008, Cuny et al. 2012). Gryc et al. (2011) witnessed the beginning of cambial activity earlier (DOY 90-105; first half of April). On the other hand, Lugo et al. (2012) observed the beginning of xylogenesis one month later. However, this author analysed black spruce stand in boreal biome in Canada characterising by short growing season and long winters with low air temperatures.

In the presented study, the effect of the tree age on the beginning of the xylogenesis was not detected. Li et al. (2012) proved the difference at the beginning of the cambial activity between old and young stands. However, significantly higher stands' age variation than in our study can cause the discrepancy (43-45 and 162-188-year-old). Rossi et al. (2008b) reported that wood formation started first in the trees of the younger stand, particularly on May 10 (DOY 131) and May 31 (DOY 152) in the young and old mixed stands with Norway spruce, respectively.

The maximum number of $\mathrm{CC}$ was recorded at the same time in the young as well as old stand, on May 17 (DOY 138). This date almost coincides with the time of first wood cells' observation. Generally, a higher number of $\mathrm{CC}$ indicates a higher cambial activity. Therefore, the number of $\mathrm{CC}$ can serve an indicator of the cambial activity. An average of the maximum CC number was 13 and 11 cells in the young and old stands, respectively. The effect of the stand age on the number of the cells in the cambial zone and the timing of their maximum activity is evident. Gričar (2007) observed that most of CC (more than 14) were formed between June 9 (DOY 160) and June 20 (DOY 171). Gryc et al. (2011) also reported the maximum number of CC 10 on average, occurring in June (DOY 151-181). Similar results were revealed by Rossi et al. (2009), who observed that the number of CC ranged between 5 and 9 during June (DOY 154-175).

Cambial activity finished on September 13 (DOY 256) and September 20 (DOY 263) in the young and old stands, respectively. Gryc et al. (2012) revealed the finish of PC cell formation in the second half of August (DOY 224-239), and Gričar (2007) even noted an earlier end (around DOY 212). The duration of the cambial activity depends on the species, site fertility, and growing season climate conditions. Tumajer et al. (2017) considered mainly air temperature and amount of precipitation as the principal limiting factors. According to Rossi et al. (2014), the relationship between temperature and most phenological phases of xylogenesis is linear. Contrariwise, $\mathrm{He}$ 
et al. (2019) found that $81 \%$ of radial growth is driven by soil moisture. Rossi at al. (2008a) recorded dependence on the age of trees and the duration of the cambial activity. Under these circumstances, it seems that the cambium responded differently to external factors, primarily based on the age of individual trees.

The maximum daily increment of the cells was 0.84 and 1.71 cell per day in the young and old stand, respectively (DOY 166, 173; mid-June). Gryc et al. (2012) reported 0.66 to 0.92 (mid-June-mid-July). Rossi et al. (2006b) found out those conifers (both in Europe and North America) reach the maximum cell increment around the summer solstice when the photoperiod is the longest. The daily increase was 0.57 and 0.49 cell per week for the young and old trees, respectively. Gryc et al. (2011) calculated the daily increment of the wood cells to be 0.34 . Rossi et al. (2008b) prove the lower rates of cell production (0.35 to 0.69 in mature sample trees). In the present study, the average daily increment was 0.33 and 0.26 cell per day in the young and old sample trees, respectively.

The first phloem cells were formed in all of the trees during April or at the end of March. Gričar and Čufar (2008) observed the primary phloem cells at the end of April. The number of early phloem cells (EP) averaged four cells independent of the age. Most of these cells were formed during June and July. According to Alfieri and Evert (1968), the production of almost all new phloem cells took place in May. Similar results reported Gričar and Čufar (2008) who found that the early phloem was represented by a layer of 4-6 cells, which were formed before mid-June in most of the sample trees. Late phloem (LP) was represented by five cells on average, regardless of the tree age. The finding is in line with Antonova and Stasova (2006) who detected approximately $4.5-5.2$ phloem cells formed by the cambial elements during several growing seasons.

The first axial parenchyma appeared during May. This result agrees with Gričar et al. (2006), who observed the first axial parenchyma cells in mid-May; the author considers this time as the beginning of late phloem growth (LP). The activity of these processes depends on the weather (Antonova and Stasova 1993).

Based on the Pearson correlation coefficient, it was assessed the relationship between the week cells increment and the air temperature before sampling. This fact was confirmed independently on the age of trees. The old trees responded more strongly than the young trees (i.e. $r=0.45$ and $r=0.33$, respectively). Nevertheless, the air temperature is the control factor of cell development. Hacura et al. (2014) validated the link between air temperature and cells formation. Besides, Li et al. (2012) concluded that the young and old trees in their study responded to the air temperature, as well as results in this study. However, the reaction of the old trees was almost none $(r=0.08)$ in the case of precipitation opposed young trees $(r=0.37)$. Results show more sensitivity to the precipitation of the young trees. It can be caused by greater plasticity in response on the water regime of the younger organism, distribution of root system etc. Li et al. (2012) did not find a significant correlation between the xylem cell production and precipitation.

Newly formed phloem did not answer the amount of precipitation in both age classes. In the young stand, the correlation coefficient was even negative $(-0.32)$. While temperature positively influenced phloem cells development in the young trees $(\mathrm{r}=0.25)$ in contrast with old sample trees $(r=0.07)$. Strong dependency of these processes in the phloem on the weather was also reported by other studies (e.g. Antonova and Stasova 1993, Sevanto 2014). 


\section{CONCLUSIONS}

All microcores for the presented study were sampled from two stands of Norway spruce (Picea abies (L.) Karst.) of different age (35 and 106 years) at research plot Rájec-Němčice (the Czech Republic). The samples were taken between March 7, 2012, and November 1, 2012.

Six cells on average were detected in the cambial zone during dormancy independently on the age of trees. The young sample trees showed a higher maximum number of cells in the cambial zone. However, the young sample trees were also characterised by more considerable variability. The peak of the number of the cambial cells came in both stands at the same time. The cambial activity (the first phloem cell is completely formed) started in the period end-March till midApril. The commencement of cambial activity was observed earlier in the young stand, as well as the state of fully lignified cells. The cambial activity attained the same length ( 22 weeks) for both investigated ages, but it was shifted over time. The age of the sample tree also affected the number and efficiency of the cambial cells during the active growing season.

The beginning of the xylogenesis (the first cells at PC stage) were detected one week later in the old stand than in young stand (first half of May). On the contrary, no difference was found in the timing of SW stage, compared to MT stage, which came first in the young stand and about one week later in old stand. The maximum weekly increment was observed in the old trees at first but was lower than in the young stand. The maximum number of the cells found during the growing season was 75 and 65 for the young and old trees, respectively. The rapidity and timing of newly formed wood cells on average per week (assessed as the pointer of the cambial activity) and the maximum number of newly formed cells confirmed that the age of trees influenced the creation of newly formed cells.

Based on the results of the presented study, the correlation relationship among the air temperature, precipitation and creation of new wood cells was established. The site factors (seasonal air temperature, amount of precipitation) affected the progress of xylogenesis. On the other hand, this claim does not apply for the phloem formation. The group of old trees seems to be more resistant to external factors (especially the precipitation) in the case of xylem and phloem or their reaction is slower and need to be more pronounced.

\section{ACKNOWLEDGEMENTS}

The research was funded by the Internal Grant Agency of the Faculty of Forestry and Wood Technology of Mendel University in Brno (Project No. 43/2013 "XYLSM") and by the Ministry of Agriculture of the Czech Republic (Institution support MZE-RO0118). Authors are indebted to Petr Štelar and Jaroslav Gongol for their help with lab's work, as well as to CzechGlobe (The Academy of Science) and the Department of Ecology (Mendel University) for providing the climatic data.

\section{REFERENCES}

1. Alfieri, F.J., Evert, R.F., 1968: Seasonal development of secondary phloem in Pinus. American Journal of Botany 55(4): 518-528.

2. Antonova, G.F., Stasova, V.V., 1993: Effect of environmental factors on wood formation in Scots pine stems. Trees 7: 214-219. 
3. Antonova, G.F., Stasova, V.V., 2006: Seasonal development of phloem in Scots pine stems. Russian Journal of Developmental Biology 37(5): 306-320.

4. Bannan, M.W., 1962: Cambial behaviour with reference to cell length and ring width in Pinus strobus L. Canadian Journal of Botany 40(8): 1057-1062.

5. Černý, J., Krejza, J., Pokorný, R., Bednář, P., 2018: LaiPen LP 100 - a new device for estimating forest ecosystem leaf area index compared to the etalon: A methodologic case study. Journal of Forest Science 64(11): 455-468.

6. Cocozza, C., Palombo, C., Tognetti, R., Porta, N., Anichini, M., Giovannelli, A., Emiliani, G., 2016: Monitoring intra-annual dynamics of wood formation with microcores and dendrometers in Picea abies at two different altitudes. Tree Physiology 36(7): 832-846.

7. Cuny, H.E., Rathgeber, C.B.K., Lebourgeois, F., Fortin, M., Fournier, M., 2012: Life strategies in intra-annual dynamics of wood formation: example of three conifer species in a temperate forest in north-east France. Tree Physiology 32: 612-625.

8. Deslauriers, A., Rossi, S., Anfodillo, T., Saracino, A., 2008: Cambial phenology, wood formation and temperature thresholds in two contrasting years at high altitude in southern Italy. Tree Physiology 28(6): 863-871.

9. Diaci, J., 2002: Regeneration dynamics in a Norway spruce plantation on a silver fir-beech forest site in the Slovenian Alps. Forest Ecology and Management 161(1-3): 27-38.

10. Gričar, J., Zupančič, M., Čufar, K., Koch, G., Schmitt, U., Oven, P., 2006: Effect of local heating and cooling on cambial activity and cell differentiation in the stem of Norway spruce (Picea abies). Annals of Botany 97(6): 943-951.

11. Gričar, J., 2007: Xylo- and phloemogenesis in silver fir (Abies alba Mill.) and Norway spruce (Picea abies (L.) Karst.). Slovenian Forestry Institute. Ljubljana, 106 pp.

12. Gričar, J., Čufar, K., 2008: Seasonal dynamics of phloem and xylem formation in Silver fir and Norway spruce as affected by drought: Fiziologiya Rastenii 55(4): 597-603.

13. Gričar, J., Levanič, T., Oven, P., 2008: Parameters of Gompertz function for evaluation of wood formation dynamics expressed as number of cells or measured widths in Norway spruce. Wood Research 53(4): 1-10.

14. Gričar, J., 2008: Significance of intra-annual studies of radial growth in trees. In: TRACE - Tree rings in archaeology, climatology and ecology (ed. Kaczka RJ). Proceedings from Dendrosymposium Vol.7, April 27th-30th 2008, Zakopane, Poland. Pp 18-25.

15. Gričar, J., 2012: Cambial cell production and structure of xylem and phloem as an indicator of tree vitality: A review. In: Sustainable forest management current research (ed. Diez JJ). Pp 111-134, InTech. Rijeka, Croatia.

16. Gričar, J., Prislan, P., Gryc, V., Vavrčík, H., Martin, L., Čufar, K., 2014: Plastic and locally adapted phenology in cambial seasonality and production of xylem and phloem cells in Picea abies from temperate environments. Tree Physiology 34: 869-881.

17. Gryc, V., Vavrčík, H., Vichrová, G., 2011: Monitoring of xylem formation in Norway spruce in the Czech Republic 2009. Wood Research 56(4): 467-478.

18. Gryc, V., Hacura, J., Vavrčík, H., Urban, J., Gebauer, R., 2012: Monitoring of xylem formation in Picea abies under drought stress influence. Dendrobiology 67: 15-24.

19. Hacura, J., Gryc, V., Vavrčík, H., Hozová, J., 2014: The Effect of drought on cell wall thickness and radial dimension of tracheids of Picea abies (L.) Karst. Wood Research 60(2): 175-188.

20. Hadaš, P., 2002: Temperature and precipitation conditions in the high elevation spruce stands of the Drahanská vrchovina. Ekológia (Bratislava) 21(1): 69-87. 
21. He, M., Yang, B., Rossi, S., Bräuning, A., Shishov, V., Kang, S., 2019: Simulated and predicted responses of tree stem radial growth to climate change - A case study in semi-arid north central China. Dendrochronologia 58: 1125-7865.

22. Kijowska-Oberc, J., Staszak, A.M., Kamiński, J., Ratajczak, E., 2020: Adaptation of forest trees to rapidly changing climate. Forests 11(2): 123.

23. Kutscha, N.P., Hyland, F., Schwarzmann, J.M., 1975: Certain seasonal changes in balsam fir and its derivates: Wood Science and Technology 9(3): 175-188.

24. Larcher, W., 2003: Physiological ecology of plants: Ecophysiology and stress physiology of functional groups. 4th ed., Springer. Berlin, Heidelberg, New York, 517 pp.

25. Larson, P.R., 1994: The vascular cambium. Springer. Berlin, 727 pp.

26. Li, X., Liang, E., Gričar, J., Prislan, P., Rossi, S., Čufar, K., 2012: Age dependence of xylogenesis and its climatic sensitivity in Smith fir on the south-eastern Tibetan Plateau. Tree Physiology 33(1): 48-56.

27. Lugo, J.B., Deslauriers, A., Rossi, S., 2012: Duration of xylogenesis in Black spruce lengthened between 1950 and 2010. Annals of Botany 110(6): 1099-1108.

28. Menšík, L., Fabiánek, T., Tesař, V., Kulhavý, J., 2009: Humus conditions and stand characteristics of artificially established young stands in the process of the transformation of spruce monocultures. Journal of Forest Science 55: 215-223.

29. Panshin, A.J., de Zeeuw, C., 1980: Textbook of wood technology. McGraw- Hill. New York, $722 \mathrm{pp}$.

30. Rossi, S., Anfodillo, T., Menardi, R., 2006a: Trephor: A new tool for sampling microcores from tree stems. IAWA Journal 27(1): 89-97.

31. Rossi, S., Deslauriers, A., Anfodillo, T., 2006b: Assessment of cambial activity and xylogenesis by microsampling tree species: An example at the Alpine timberline. IAWA Journal 27(4): 383-394.

32. Rossi, S., Deslauriers, A., Anfodillo, T., Carraro, V., 2007: Evidence of threshold temperatures for xylogenesis in conifers at high altitudes. Oecologia 152(1): 1-12.

33. Rossi, S., Deslauriers, A., Anfodillo, T., Carrer, M., 2008a: Age-dependent xylogenesis in timberline conifers. New Phytologist 177(1): 199-208.

34. Rossi, S., Deslauriers, A., Gričar, J., Seo, J.W., Rathgeber, C.B.K., Anfodillo, T., Morin, H., Levani, T., Oven, P., Jalkanen, R., 2008b: Critical temperatures for xylogenesis in conifers of cold climates. Global Ecology and Biogeography 17(6): 1-12.

35. Rossi, S., Simard, S., Rathberger, C.B.K., Deslauriers, A., De Zan, C., 2009: Effects of a 20-day-long dry period on cambial and apical meristem growth in Abies balsamea seedlings. Trees 23(1): 85-93.

36. Rossi, S., Morin, H., Deslauriers, D., 2012: Causes and correlations in cambium phenology: towards an integrated framework of xylogenesis. Journal of Experimental Botany 63(5): 2117-2126.

37. Rossi, S., Girard, M.J., Morin, H., 2014: Lengthening of the duration of xylogenesis engenders disproportionate increases in xylem production. Global Change Biology 20: 2261-2271.

38. Savidge, R.A., 1996: Xylogenesis, genetic and environmental regulation. IAWA Journal 17(3): 269-310.

39. Savidge, R.A., 2000: Intristic regulation of cambial growth. Journal of Plant Growth Regulation 20: 52-77.

40. Sevanto, S., 2014: Phloem transport and drought. Journal of Experimental Botany 65(7): 1751-1759. 
41. Schweingruber, F.H., 2007: Wood structure and environment. Springer. Berlin, Heidelberg, New York, 278 pp.

42. Schweingruber, F.H., Steiger, P., Börner, A., 2019: Bark anatomy of trees and shrubs in the temperate northern hemisphere. Springer, $394 \mathrm{pp}$.

43. Speer, J.H., 2010: Fundamentals of tree-ring research. The University of Arizona Press. Tuscon, 333 pp.

44. Světlík, J., Krejza, J., Menšík, L., Pokorný, R., Mazal, P., Kulhavý, J., 2016: Carbon sequestration into a spruce stand (Picea abies (L.) Karst.) in the Drahanská vrchovina upland (Czech Republic). Reports of Forestry Research 61: 42-53.

45. Tumajer, J., Altman, J., Štěpánek, P., Treml, V., Doležal, J., Cienciala, E., 2017: Increasing moisture limitation of Norway spruce in Central Europe revealed by forward modelling of tree growth in tree-ring network. Agriculture and Forest Meteorology 247: 56-64.

46. Viewegh, J., Kusbach, A., Mikeska, M., 2003: Czech forest ecosystem classification. Journal of Forest Science 49: 74-82.

47. Walter, F.W., Lieth, H., 1960: Climate diagram world atlas. Fisher, Jena, 1960-1966.

48. Wilcox, H., 1962: Cambial growth characteristics. In: Tree Growth (ed. Kozlowski TT). Ronald Press. New York, Pp 57-88.

49. Wojdyr, M., 2010: Fityk: a general-purpose peak fitting program. Journal of Applied Crystallography 43: 1126-1128.

\author{
Jana Hacurová* \\ ${ }^{1}$ Mendel University In Brno \\ Faculty of Forestry and Wood Technology \\ Department of Wood Science \\ ZEMĚdĚLSKÁ 3, 6I3OO BRno \\ Czech Republic
}

2Forestry and Game Management Research Institute

Research Station at Opočno

Na Olivě 550, 5 I 773 Opočno

Czech Republic

*Corresponding author: janahacurova@email.cz

Jakub Hacura, Hanuš Vavrčík, Vladimír Gryc

Mendel University In Brno

Faculty of Forestry and Wood Technology

Department of Wood Science

ZEMĚdĚLSKÁ 3, 6I zOO BRno

Czech Republic

JAKUB ČERNÝ

Forestry and Game Management Research Institute

Research Station at Opočno

Na Olivě 550, 5 I7 73 Opočno

Czech Republic 
